\title{
Management of Animal Botulism Outbreaks: From Clinical Suspicion to Practical Countermeasures to Prevent or Minimize Outbreaks
}

Anniballi, Fabrizio; Fiore, Alfonsina; Löfström, Charlotta; Skarin, Hanna; Auricchio, Bruna; Woudstra, Cédric; Bano, Luca; Segerman, Bo; Koene, Miriam; Båverud, Viveca

Total number of authors:

16

Published in:

Biosecurity and Bioterrorism

Link to article, DOI:

10.1089/bsp.2012.0089

Publication date:

2013

Document Version

Publisher's PDF, also known as Version of record

Link back to DTU Orbit

Citation (APA):

Anniballi, F., Fiore, A., Löfström, C., Skarin, H., Auricchio, B., Woudstra, C., Bano, L., Segerman, B., Koene, M., Båverud, V., Hansen, T., Fach, P., Åberg, A. T., Hedeland, M., Engvall, E. O., \& De Medici, D. (2013).

Management of Animal Botulism Outbreaks: From Clinical Suspicion to Practical Countermeasures to Prevent or Minimize Outbreaks. Biosecurity and Bioterrorism, 11(Supplement 1), S191-S199.

https://doi.org/10.1089/bsp.2012.0089

\section{General rights}

Copyright and moral rights for the publications made accessible in the public portal are retained by the authors and/or other copyright owners and it is a condition of accessing publications that users recognise and abide by the legal requirements associated with these rights.

- Users may download and print one copy of any publication from the public portal for the purpose of private study or research.

- You may not further distribute the material or use it for any profit-making activity or commercial gain

- You may freely distribute the URL identifying the publication in the public portal 


\section{Management of Animal Botulism Outbreaks: From Clinical Suspicion to Practical Countermeasures to Prevent or Minimize Outbreaks}

Fabrizio Anniballi, Alfonsina Fiore, Charlotta Löfström, Hanna Skarin, Bruna Auricchio, Cédric Woudstra, Luca Bano, Bo Segerman, Miriam Koene, Viveca Båverud, Trine Hansen, Patrick Fach, Annica Tevell Åberg, Mikael Hedeland, Eva Olsson Engvall, and Dario De Medici

Botulism is a severe neuroparalytic disease that affects humans, all warm-blooded animals, and some fishes. The disease is caused by exposure to toxins produced by Clostridium botulinum and other botulinum toxin-producing clostridia. Botulism in animals represents a severe environmental and economic concern because of its high mortality rate. Moreover, meat or other products from affected animals entering the food chain may result in a public health problem. To this end, early diagnosis is crucial to define and apply appropriate veterinary public health measures. Clinical diagnosis is based on clinical findings eliminating other causes of neuromuscular disorders and on the absence of internal lesions observed during postmortem examination. Since clinical signs alone are often insufficient to make a definitive diagnosis, laboratory confirmation is required. Botulinum antitoxin administration and supportive therapies are used to treat sick animals. Once the diagnosis has been made, euthanasia is frequently advisable. Vaccine administration is subject to health authorities' permission, and it is restricted to a small number of animal species. Several measures can be adopted to prevent or minimize outbreaks. In this article we outline all phases of management of animal botulism outbreaks occurring in wet wild birds, poultry, cattle, horses, and fur farm animals.

B OtUlism is a SEVERE NeUroparalytic Disease that affects humans, all warm-blooded animals, and some fishes. The illness is caused by exposure to botulinum neurotoxins (BoNTs), which are produced by anaerobic, spore-forming, ubiquitous microorganisms belonging to

the genus Clostridium, referred to as BoNT-producing clostridia. BoNTs act on nerve endings blocking acetylcholine release. Their potency depends on 2 factors: their enzymatic activity and their selective affinity for binding neurons. ${ }^{1,2}$ Human disease does not differ fundamentally

Fabrizio Anniballi, CLT, is a Laboratory Technician; Alfonsina Fiore, PhD, is a Researcher; Bruna Auricchio, CLT, is a Laboratory Technician; and Dario De Medici, PhD, is Senior Researcher, all at Istituto Superiore di Sanità (ISS), Department of Veterinary Public Health and Food Safety, Rome, Italy. Charlotta Löfström, PhD, is an Assistant Professor, and Trine Hansen, MSc, is a PhD student, both at the National Food Institute, Technical University of Denmark (DTU), Søborg, Denmark. Hanna Skarin, MSc, is a Research Assistant; Bo Segerman, PhD, is is a Researcher; Viveca Båverud, PhD, is Associate Professor; Eva Olsson Engvall, PhD, is Associate Professor; all in the Department of Bacteriology, National Veterinary Institute (SVA), Uppsala, Sweden, and Department of Biomedical Sciences and Veterinary Public Health, Swedish University of Agricultural Sciences (SLU), Uppsala, Sweden. Cédric Woudstra, MSc, is an Engineer, and Patrick Fach, PhD, is Head of the High Throughput qPCR Platform IdentyPath, both at the French Agency for Food, Environmental and Occupational Health Safety (ANSES), Food Safety Laboratory, Maisons-Alfort, France. Luca Bano, PhD, is Veterinary Officer, Istituto Zooprofilattico Sperimentale delle Venezie (IZSVe), Veterinary Diagnostic Laboratory of Treviso, Treviso, Italy. Miriam Koene, DVM, is a Scientist, Central Veterinary Institute of Wageningen University and Research Centre (CVI), Lelystad, the Netherlands. Annica Tevell Åberg, PhD, is a Senior Researcher, and Mikael Hedeland, PhD, is Associate Professor and Deputy Head of the Department, Department of Chemistry, Environment and Feed Hygiene, National Veterinary Institute (SVA), Uppsala, Sweden. 
in clinical features, diagnosis, supportive laboratory testing, management, or therapeutic measures from that seen in veterinary practice, but the rarity of human botulism contrasts with the frequent occurrence of animal botulism. ${ }^{3,4}$ On a worldwide basis, avian botulism probably represents the most important disease of migratory birds. More than a million deaths have been reported in relatively localized outbreaks in a single year, and outbreaks with losses of 50,000 birds or more are relatively common. ${ }^{5}$

Botulism in animals represents a serious environmental and economic concern because of the high mortality observed during the outbreaks. BoNTs and BoNT-producing clostridia represent an additional concern because of their potential use as biological weapons. ${ }^{6,7}$ A bioterrorist attack directed at a livestock population by means of viruses, microorganisms, or toxins could instill fear among the population and cause major economic consequences; thus, livestock agroterrorism has caught the attention of government policymakers in most countries. ${ }^{8}$ It may be difficult to attribute an animal disease outbreak to a biological attack. In fact, unlike bioterrorism attacks directed toward humans, bioterrorism attacks on livestock or poultry would have fewer indications that could be used to distinguish them from natural outbreaks. ${ }^{8}$ The countermeasures to prevent a possible agroterrorism attack include sharing information among government agencies, improving veterinary and public health awareness, and supporting research to identify new, more efficient and rapid methods to combat these threats. ${ }^{8}$

This article outlines phases of management of animal botulism outbreaks from clinical suspicion to practical countermeasures to prevent or minimize outbreaks occurring in waterfowl, poultry, cattle, horses, and fur farm animals, in the framework of the activities promoted by the European research project AniBioThreat (www.anibiothreat.com).

\section{BoNT-Producing Clostridia AND Their ToXins}

The species Clostridium botulinum and some strains of Clostridium baratii and Clostridium butyricum are currently classified as BoNT-producing clostridia. On the basis of their genotypic, phenotypic, and biochemical characteristics, these strains are divided into 6 groups: $C$. botulinum (groups I-IV), C. butyricum, and C. baratii. Groups I and II, C. butyricum, and C. baratii are mainly associated with human botulism, whereas group III organisms are mainly responsible for animal botulism. ${ }^{1,2}$ Group IV organisms, also known as Clostridium argentinense, are associated with wound botulism. ${ }^{9}$ On the basis of the BoNTs produced, these strains can additionally be classified in 7 groups, from A to G. ${ }^{1,2}$ Group I and II organisms are capable of producing type $\mathrm{A}, \mathrm{B}, \mathrm{E}$, and $\mathrm{F}$ toxins; group III organisms can produce type $\mathrm{C}, \mathrm{D}$, and their mosaic $\mathrm{C} / \mathrm{D}$ and $\mathrm{D} / \mathrm{C}$ toxins. ${ }^{10-12}$ Group IV, C. butyricum, and C. baratii produce type G, E, and F toxins, respectively. Some strains are also capable of producing 2 toxins simultaneously or may carry a second silent nonexpressed gene. ${ }^{13,14}$

C. botulinum strains play a vital role in the natural carbon recycling process, growing in decaying organic matter (eg, animal carcasses) and producing high levels of BoNTs. High protein substrates are essential because $C$. botulinum lacks the ability to synthesize certain essential amino acids. Also, $\mathrm{pH}$ and salinity in the sediments together with temperature play a crucial role for growth and toxin production, with an optimum growth temperature between $25^{\circ} \mathrm{C}$ and $42^{\circ} \mathrm{C} .^{4,5,15}$ Type $\mathrm{D}$ strains can produce toxin in carrion at a temperature as low as $9^{\circ} \mathrm{C}$, whereas a type $\mathrm{C}$ strain failed almost completely to do it at $16^{\circ} \mathrm{C}^{16}$

BoNT-producing clostridia secrete the toxins during their vegetative growth as inactive single-chain polypeptides that subsequently are activated by bacterial or tissue protease. In nature BoNTs are found as progenitor toxins containing the neurotoxin and nontoxic associated proteins, probably responsible for protecting the neurotoxin from environmental factors. ${ }^{17}$ Genes encoding BoNTs can be located on the chromosome or on extrachromosomal elements, such as plasmids or bacteriophages. ${ }^{18-20}$ Specifically, toxin genes for group III organisms are carried by bacteriophages that exert an unstable lysogenic cycle. Molecular and genomic analysis of the bacteriophage genome revealed that this phage exists as a circular plasmid prophage in the lysogenic state, and it does not integrate into the host chromosome. ${ }^{21}$

The sensitivity to BoNTs seems to be widely variable among the different animal species. Cattle botulism is most frequently caused by type $\mathrm{D}$ or $\mathrm{D} / \mathrm{C}$ toxin, followed by type $\mathrm{C}$ toxin, although type $\mathrm{A}, \mathrm{B}$, and $\mathrm{C} / \mathrm{D}$ toxin types have also been reported. In wild birds, the most common toxin isolated is type $\mathrm{C}$ and for fish-eating waterfowl type $\mathrm{E}$. In contrast, in poultry the most common toxins are type $\mathrm{C}$ and $C / D$, although type $A$ has been reported. The mosaic toxin type $\mathrm{C} / \mathrm{D}$ seems to be more lethal to chickens than type $\mathrm{C}$ toxin. ${ }^{10}$ In addition, birds may harbor type $\mathrm{D} C$. botulinum strains in their gut without showing symptoms. ${ }^{22}$ Equine botulism is caused by type B, C, and A toxins. ${ }^{22-25}$ Fur farm animals (eg, fox, ferret, mink) seem to be susceptible to type $\mathrm{C}$ and type $\mathrm{C} / \mathrm{D}$ toxins, but rare outbreaks due to type $\mathrm{A}$ and $\mathrm{E}$ toxins have also been reported. $^{22,26,27}$

\section{Pathogenesis and Pathophysiology}

BoNT is the etiological agent of human and animal botulism. As extensively reported elsewhere, the BoNT mechanism of action consists of the following steps: The active toxin is absorbed in the small intestine by binding to the receptors on the apical surface of gut epithelial cells. It is then released into the general circulation, reaching all peripheral cholinergic nerve endings. In these sites, the toxin 
binds to specific receptors and is internalized into the cytosol of the nerve terminus, where it blocks the release of acetylcholine, producing the characteristic paralysis. ${ }^{28,29}$

For animal botulism, as well as for human botulism, the primary contamination route is the ingestion of preformed toxins in foods or feeds. Raw material, such as grass, hay, rotting vegetation, and slaughterhouse waste, as well as decay of vertebrate carcasses, invertebrates, and sewage may support BoNT-producing clostridia growth and toxin production. Animals may directly ingest decaying organic matter containing toxin, or they may ingest toxins through the consumption of zooplankton or invertebrates, such as larvae, that have consumed toxic material.

Fly larvae and other invertebrates are unaffected by the toxin, but feeding on toxigenic carcasses may concentrate toxin. Ingestion of a single toxigenic maggot could be lethal. This is described as the carcass-maggot cycle of botulism. ${ }^{30}$ There is also some evidence that exposure to poultry litter as feed or bedding may constitute a risk factor in the occurrence of cattle botulism. ${ }^{31-33}$ Typically, type C and $\mathrm{D}$ toxins are associated with carrion of birds or small animals that have contaminated water, feed, or the environment, while noncarrion-associated botulism is caused by type $\mathrm{A}$ and $\mathrm{B}$ toxins. ${ }^{4,33-35}$

A second form of animal botulism is associated with the absorption of BoNTs produced in vivo in the intestinal tract. This form of botulism, seen in chickens and horses, can be categorized as a toxicoinfection. ${ }^{36,37}$ Böhnel and colleagues describe a toxicoinfection in cattle, referred to as "visceral botulism." 38 This form of animal botulism is hypothesized to occur when $C$. botulinum colonizes the lower section of the intestine. BoNT is formed and partially absorbed by mucous membrane, and the rest is excreted with the feces. Excretion of feces containing BoNTs by animals that do not show any clinical symptoms of acute paralysis may demonstrate the production of toxins in the lower sections of intestines where only a low amount is absorbed, in contrast to the proximal parts of the intestinal tract in which toxins are highly absorbed. ${ }^{38}$

A third form of animal botulism is caused by the germination and production of BoNTs by C. botulinum spores in infected wounds. ${ }^{3,37,39}$ The last 2 forms are often referred to as toxicoinfectious form botulism.

\section{Clinical Manifestations}

All forms of botulism are characterized by a progressive, symmetrical, flaccid paralysis that often starts in the hindquarters with weakness, muscle tremors, stumbling, and recumbency and often results in death. The speed of progression is variable, resulting in peracute, acute, and chronic forms of the disease. Some cases may present as sudden deaths. Depending on the amount of ingested toxin, initial signs may be subtle or overt. Generally, the clinical signs appear from 24 hours up to 17 days. In monogastric animals, the incubation period of foodborne botulism is usually shorter than for ruminants, in which clinical signs may be absent for over a week. For toxicoinfectious forms, the incubation period is usually longer, and an indicative period of 4 to 14 days has been reported in the literature. ${ }^{3,22,40}$

Signs of the intoxication include reluctance of the animals to rise; the lying posture may be abnormal, and, on rising, the gait may be stilted and the hind limbs splayed and ataxic. Weakness then progresses to the forequarters, head, and neck. An abnormal posture of the head may be evident. Apparent lethargy, depression, and dullness of expression may be the results of loss of tone around the eyes and mouth. The eyes may appear closed, the pupils dilated, and pupillary reflexes sluggish. ${ }^{3}$

\section{Clinical Manifestations in Birds}

In birds, the flaccid paralysis progresses cranially from the legs, to include wings, neck, and eyelids. Initially, affected birds are unable to sustain flight or show uncoordinated flight and may be found sitting and reluctant to move. They seem lame, and the wings may droop when paralyzed. Paralysis of the inner eyelid or nictitating membrane and neck muscles follows, resulting in the inability to hold the head erect. Birds may also appear lateral or ventral recumbent and comatose or dead. ${ }^{3,40,41}$ Recumbent birds intermittently stand and walk a few steps. Often they cannot stand up completely and even walk on their tarsometatarsi. More severely affected water birds are unable to walk and drag themselves forward using their wings and beak. ${ }^{5,40,41}$ Broilers generally appear ruffled and often show defeathered areas on the back. Affected chickens may have soiled vents caused by diarrhea. ${ }^{40,42,43}$

\section{Clinical Manifestations in Cattle}

Cattle in the early stage of the disease appear listless, reluctant to move, and stiff. Constipation and signs of colic may be present at this stage. Weakness in the hind limbs results in difficulty rising, and affected cattle therefore often appear recumbent. Dysphagia is present in most, but not all, cases of botulism in cattle. Decreased masseter tone, decreased tongue strength, and pharyngeal paresis or paralysis may contribute to dysphagia, each in variable degree. At this stage the animals remain bright and alert and usually are able to eat the grass around them and drink water from a bucket. As the paralysis progresses, they may become unable to eat and drink, they may be laterally recumbent with terminal abdominal breathing, and the tongue may lose reaction strength and become completely paralyzed. Other clinical signs include photophobia, sluggish rumen movements, reduced anal tone, and tail paralysis. ${ }^{34}$ Atypical clinical presentation can appear in cattle because of the ingestion of BoNT/B, including diarrhea, profuse salivation, regurgitation, and vomiting. ${ }^{40}$ 


\section{Clinical Manifestations in Horses}

The clinical signs in horses are similar to those in cattle. The main signs in adult horses are generalized muscle weakness and dysphagia; decreased tail, eyelid, and tongue tone; mydriasis; and prolonged pupillary light reflex, frequently followed by recumbency, respiratory failure, and death. Further signs such us anorexia, weight loss, colic, hypersalivation, and tachycardia are common. ${ }^{22-25}$ Horses with type $\mathrm{C}$ botulism may have more prominent mydriasis, more labored breathing, or less dysphagia than horses with type A or B botulism. ${ }^{23}$

In foals, the "shaker foal syndrome" appears to be similar to infant botulism. The initial presenting sign is often the onset of muscle tremors leading to recumbency. Dysphagia; constipation; reduced eyelid, tongue, and tail tone; mydriasis; sluggish pupillary light reflexes; and frequent urination may also be seen. ${ }^{25}$

\section{Clinical Manifestations in Fur Farm Animals}

In fur farm animals, the most typical clinical picture includes the same clinical signs as those in large domestic animals. Paralysis of the hind legs, total paralysis, and recumbency are common. Foxes with milder symptoms often take a sitting position, dragging the rear part of their bodies. ${ }^{26}$ In ferrets, clinical signs include weakness, ataxia, ascending paralysis, blepharospasm, photophobia, and urinary incontinence, with death resulting from respiratory failure. The progression of botulism can be very fast in fur animals. In some cases, animals that have appeared well have died only 2 or 3 hours later. ${ }^{44}$

\section{DiAgNOSIS}

\section{Clinical Signs}

Clinical signs of animal botulism are often strongly indicative but not specific. A presumptive diagnosis is based on a combination of signs observed in sick animals, the duration of the outbreak, and the postmortem findings and by ruling out other differential diagnoses.

Avian botulism most often afflicts waterfowl in the season when they are flightless because of wing molt. It is therefore essential to distinguish between birds in molt and birds with early stages of botulism, since the behavior of these birds may be similar. Molting birds are very difficult to catch, whereas birds that are suffering from botulism can easily be captured when they lose the ability to dive to escape pursuit. Birds at this level of intoxication still have a high probability of surviving if they are properly treated. During outbreaks it is common to find healthy, sick, and dead animals in the same area.

In cattle, clinical signs (especially flaccid paralysis), the epidemiology of the outbreak, the clinical chemistry (es- pecially hyperglycemia, although this can occur in any cow with a severe life-threatening disease), and neutrophilia support the diagnosis. ${ }^{28,38}$ Differential diagnosis includes hypocalcemia, hypomagnesemia, carbohydrate overload, and toxicosis, including from mycotoxin, lead, nitrate, organophosphate, atropine or atropine-like alkaloid, tick paralysis, and paralytic rabies. $3,34,45$

In horses, weakness, decreased eyelid tone, decreased or absent tongue tone, decreased tail and anal tone, sluggish pupillary light reflex, and occasional episodes of slow and uncoordinated padding support the diagnosis. Differential diagnosis includes toxic plant poisoning, organophosphate intoxication, equine viral encephalitis, central nervous system trauma, equine protozoal myeloencephalitis, aberrant larval migration, and hyperammonemia. ${ }^{35}$ In horses that feed in a group, the dominant horse eats first and is therefore usually the first one to develop clinical signs and shows most rapid progression of the neurotoxic syndrome. ${ }^{35}$

\section{Postmortem Examinations}

Postmortem examination is usually unremarkable, although in more protracted cases, secondary pathologies may be present. Negative postmortem results can be used as a diagnostic tool per exclusionem. ${ }^{22}$ Diffuse intestinal hemorrhage may be observed on postmortem examination, as some strains of $C$. botulinum type $C$ and $D$ also produce an enterotoxin, but these changes are not consistent or sufficiently specific to confirm a diagnosis. Nevertheless, a full necropsy should be carried out on as many cases as possible to help rule out other conditions. In particular, stomach contents should be examined for evidence of suspicious material (eg, decayed carcass material, bones, maggots). ${ }^{34,41}$

Avian botulism should be suspected when maggots are found as part of the ingesta of gizzard contents of dead birds; however, such findings are rare. ${ }^{5}$ A presumptive diagnosis is often based on a combination of signs observed in sick animals.

Specific neurophysiological studies such as repetitive nerve stimulations have been particularly useful as a diagnostic aid for neuromuscular disease. In large animal neurology, the use of electrodiagnostics has been limited compared with other species. Aleman and colleagues summarized neurophysiological studies conducted on foals. ${ }^{46}$

In horses, edema of the head and neck may be a prominent, although inconsistently observed, necropsy finding associated with botulism. In some cases, edema might be attributable to simple hydrostatic mechanisms, secondary to the unnaturally prolonged static posture. ${ }^{35}$

\section{Laboratory Confirmation}

Laboratory confirmation can be done by demonstrating: (1) BoNTs in serum, gastrointestinal content, liver, and wound; (2) BoNT-producing clostridia in gastrointestinal 
content, liver, and wound; (3) BoNTs or BoNT-producing clostridia in feed or the close environment of the sick animal; or (4) an antibody response in an animal with symptoms of botulism. ${ }^{22,47}$ Demonstration of BoNTs in serum, feed material, or intestinal content by the mouse bioassay remains the gold standard for laboratory confirmation of botulism. However, a negative mouse bioassay does not exclude the botulism diagnosis, because the toxin may be present at a level below the limit of detection or may have been biodegraded by microbes in the intestinal tract of the animals. ${ }^{48}$ Since BoNT-producing clostridia are not a normal inhabitant of the gut, but are present in the alimentary tract of animals that have recently ingested contaminated material, demonstration of spores in the gastrointestinal contents or tissue of animals with symptoms is indicative of botulism. This is supported by the clinical diagnosis, as well as demonstration of neutralizing antibodies, and may allow a retrospective diagnosis in recovered animals. Demonstration of BoNT-producing clostridia or BoNTs in feed given to animals that show symptoms of botulism may also help to identify the source of contamination in order to prevent further cases. ${ }^{45}$

Because the use of in vivo assays is discouraged for ethical reasons, a number of alternative methods have been developed, and some of them have been validated. ${ }^{47,49,50}$

Serum, ruminal or gastrointestinal content, fecal material, tissue samples, and feed for laboratory investigation should be collected as soon as possible after the onset of the illness, or after death, to enable efficient detection of C. botulinum and/or its toxins.

\section{Treatment}

When botulism is suspected, the first critical therapeutic step is to give polyvalent antitoxin to affected animals. Antitoxin treatment should be initiated as soon as possible, because it is effective only against circulating toxin and not when toxin is fixed at the neuromuscular junction. Antibiotic administration is indicated only when there is a suspicion of inhalation pneumonia or wound infection. Clostridiocidal drugs may lyse vegetative cells of BoNTproducing clostridia, thereby increasing the amount of free toxin in the intestinal tract. Aminoglycosides may potentiate neuromuscular weakness and a nondepolarizing type of neuromuscular block. Although antibiotic treatment is discouraged, beta-lactams have been successfully used to treat poultry affected by the toxicoinfection form of botulism. Other therapies include supportive care (oral water and electrolytes) and reduced physical activity. ${ }^{32,51,52}$ For cattle, vaccination can be considered to be effective as a therapeutic treatment in an outbreak situation.

Waterfowl can recover from botulism by being administered antitoxins or being provided fresh water and shade. Treated birds should be maintained in pens that provide free access to fresh water, shade, the opportunity for recovered birds to fly out, and minimal disturbance. ${ }^{5}$ Once the diagnosis has been made, euthanasia is frequently advised to avoid problems in maintaining the animals' welfare. ${ }^{40,52}$

\section{Prevention}

Countermeasures to prevent or minimize feedborne botulism are based on: (1) providing safe and high-quality feed to farm animals; (2) properly storing animal feed; (3) inspecting water sources for dying or dead small animals and birds; (4) avoiding spreading poultry litter that contains birds or dead animals on pastures; (5) avoiding using poultry litter as bedding material; and (6) vaccinating animals. These measures are described in more detail below.

\section{Ensuring High-Quality Feed for Farm Animals}

Feed producers and suppliers should apply good manufacturing practices and good agricultural practices to ensure that fields are not spread with poultry litter containing carcasses or others materials that may support the growth of $C$. botulinum, as requested by EU legislation. ${ }^{53,54}$ Farmers should check the quality of the raw materials used for silage and eliminate those presenting traces of contamination with molds or that appear rotten or spoiled. The current methods of mixing and distributing feeds, especially in cattle farms, mean that a small quantity of a contaminant can easily be distributed. Farmers must take precautions to avoid contamination of feed ingredients. ${ }^{55}$

Animal feed prepared without acidification is particularly liable to growth and toxin production of BoNTproducing clostridia. However, acidification does not necessarily eliminate the risk of toxin formation in a carcass, unless it is chopped into small pieces and the cells or spores present in the carcass are exposed to the acid. Moreover, decomposing carcasses may contain large amounts of preformed toxin that may be further spread to the feed on processing. ${ }^{56}$

\section{Mitigating Environmental Conditions}

Preventing avian botulism outbreaks in waterbirds depends on a thorough understanding of the interactions between the agent, the host, and the environment. Because C. botulinum spores are ubiquitous in wetlands, attempts to reduce or eliminate the agent are not currently feasible. However, some actions can be carried out to mitigate environmental conditions that increase the likelihood of outbreaks. Wetland flooding and draining, pesticides, and other agricultural pollutants, as well as anoxia of the wetland bottom, may kill or change aquatic life and provide more substrates for the growth and toxin production of BoNT-producing clostridia. ${ }^{5,41}$ Reduction of organic inputs into wetlands and elimination of factors that introduce 
large amounts of decaying matter, as well as a prompt removal and proper disposal of vertebrate carcasses (applicable also in farms), are efficient measures to remove substrate, thus reducing growth and toxin production of BoNT-producing clostridia. $5,43,57,58$

\section{Vaccination}

Preventing botulism can be efficiently achieved by vaccination, which generates neutralizing antibodies against BoNTs. Vaccine administration is subject to health authorities' permission and in the EU to Directive 2001/82/ EC of the European Parliament and of the Council. ${ }^{59}$ A list of available vaccines is reported in Table 1 .
In some countries in which botulism is endemic, cattle have been routinely vaccinated against type $C$ and type $D$ toxins. For example, in Israel the vaccination program for cattle starts when they are 2 months old and consists of 2 doses 4 weeks apart followed by an annual booster. Vaccination of cattle with bivalent toxoids conferred considerable immunity following exposure to BoNTs for extended time periods. ${ }^{60}$

Immunization has been successfully adopted for broilers grown on farms with recurrent cases of the disease and for pheasants and ducks. In waterfowl, immunization might be used to reduce the risk of reintoxication. Usually, 2 doses of vaccine administered about 14 days apart are used. ${ }^{61}$ The degree of protection afforded by toxoid vaccination is

Table 1. List of Botulism Vaccines

\begin{tabular}{|c|c|c|c|c|c|}
\hline Product Name & $\begin{array}{l}\text { BoNT } \\
\text { Type }\end{array}$ & Animal Species & \multicolumn{2}{|c|}{ Dosage } & Producer \\
\hline Ultravac botulinum & $\begin{array}{l}\text { C } \\
\mathrm{D}\end{array}$ & $\begin{array}{l}\text { Cattle } \\
\text { Sheep }\end{array}$ & $\begin{array}{l}2.5 \mathrm{ml} \text { cattle } \\
1.0 \mathrm{ml} \text { sheep }\end{array}$ & $\begin{array}{l}\text { 1st dose; } 2 \text { nd dose after } \\
4-6 \text { weeks } \\
\text { Annual booster }\end{array}$ & Pfizer Animal Health \\
\hline Longrange & $\begin{array}{l}\mathrm{C} \\
\mathrm{D}\end{array}$ & Cattle & $2.5 \mathrm{ml}$ & $\begin{array}{l}\text { 1st dose from } 6 \text { weeks } \\
\text { Annual booster }\end{array}$ & Pfizer Animal Health \\
\hline $\begin{array}{l}\text { Singvac } 1 \text {-year } \\
\text { botulinum }\end{array}$ & $\begin{array}{l}\text { C } \\
\text { D }\end{array}$ & Cattle & $2.0 \mathrm{ml}$ & $\begin{array}{l}1 \text { dose } \\
\text { Annual booster }\end{array}$ & Virbac Animal Health \\
\hline $\begin{array}{l}\text { Singvac 3-year } \\
\text { botulinum }\end{array}$ & $\begin{array}{l}\mathrm{C} \\
\mathrm{D}\end{array}$ & Cattle & $2.0 \mathrm{ml}$ & $\begin{array}{l}1 \text { dose } \\
\text { Booster after } 36 \\
\text { months }\end{array}$ & Virbac Animal Health \\
\hline $\begin{array}{l}\text { Websters LV } \\
\text { Bivalent botulinum }\end{array}$ & $\begin{array}{l}\text { C } \\
\text { D }\end{array}$ & $\begin{array}{l}\text { Cattle } \\
\text { Sheep }\end{array}$ & $\begin{array}{l}2.0 \mathrm{ml} \text { cattle } \\
1.0 \mathrm{ml} \text { sheep }\end{array}$ & $\begin{array}{l}\text { 1st dose; } 2 \text { nd dose after } \\
\text { 4-6 weeks } \\
\text { Annual booster }\end{array}$ & Virbac Animal Health \\
\hline Botulism Vaccine & $\begin{array}{l}\text { C } \\
\text { D }\end{array}$ & $\begin{array}{l}\text { Cattle } \\
\text { Horses } \\
\text { Mules } \\
\text { Sheep } \\
\text { Goats }\end{array}$ & $\begin{array}{l}1.0 \mathrm{ml} \text { sheep and goats } \\
2.0 \mathrm{ml} \text { cattle, horses, } \\
\text { and mules }\end{array}$ & $\begin{array}{l}\text { 1st dose; } 2 \text { nd dose after } \\
4-7 \text { weeks } \\
\text { Annual booster }\end{array}$ & $\begin{array}{l}\text { Onderstepoort Biologi- } \\
\text { cal Products }\end{array}$ \\
\hline Botvax B & B & Horses & $2.0 \mathrm{ml}$ & $\begin{array}{l}3 \text { doses at } 1 \text {-month in- } \\
\text { tervals } \\
\text { Annual booster }\end{array}$ & Neogeon Corporation \\
\hline Febrivac 3 plus & $\mathrm{C}$ & Mink & $1.0 \mathrm{ml}$ & $\begin{array}{l}\text { Single dose } \\
\text { Annual booster }\end{array}$ & $\begin{array}{l}\text { Impfstoffwerk-Dessau- } \\
\text { Tornau Gmbh }\end{array}$ \\
\hline Biocom- D & $\mathrm{C}$ & Mink & $1.0 \mathrm{ml}$ & $\begin{array}{l}\text { Single dose, Booster as } \\
\text { kit vaccination }\end{array}$ & United Vaccines, Inc. \\
\hline Biocom -P & $\mathrm{C}$ & Mink & $1.0 \mathrm{ml}$ & $\begin{array}{l}\text { Single dose, Booster as } \\
\text { kit vaccination }\end{array}$ & United Vaccines, Inc. \\
\hline Biocom & $\mathrm{C}$ & Mink & $1.0 \mathrm{ml}$ & $\begin{array}{l}\text { Single dose, Booster as } \\
\text { kit vaccination }\end{array}$ & United Vaccines, Inc. \\
\hline Botumink & $\mathrm{C}$ & Mink & $1.0 \mathrm{ml}$ & $\begin{array}{l}\text { Single dose, Booster as } \\
\text { kit vaccination }\end{array}$ & United Vaccines, Inc. \\
\hline
\end{tabular}


influenced more by the time and number of inoculations than by the amount of toxoid injected. ${ }^{62}$

Foals can be vaccinated as early as 2 weeks of age. Their immunization can be achieved by vaccinating pregnant mares, considering the high titer of antibotulism antibodies found in the colostrum. Vaccinated foals or adult horses have to receive an annual booster. ${ }^{63}$

In the US, minks have been vaccinated against botulism since the 1950s. ${ }^{64}$ In Europe, mink are the only animal species routinely treated, although cattle, horses, and pheasants are sometimes vaccinated in outbreak situations. ${ }^{65}$

\section{CONClusion}

According to EU legislation, botulism is a communicable disease to be covered by the European epidemiologic surveillance network, as well as a zoonosis to be monitored according to the epidemiologic situation. ${ }^{62}$ Member states annually report the number of human cases that have occurred in their countries to the European Centre for Disease Prevention and Control (ECDC) and the European Food Safety Agency (EFSA), but no notification procedures are foreseen for animal disease. The lack of compulsory notification of the disease in animals hampers an accurate knowledge of European cases and outbreaks and results in an underestimation of the incidence. Although botulism in animals is not reported, the illness can be classified in Europe as an emerging disease. ${ }^{65}$ The increase in the number of cases of animal botulism during the past decade is probably due to the lack of use of antimicrobial drugs in feed and the publication of the European Directive 2003/99/EC on the monitoring of zoonoses and zoonotic agents. ${ }^{66}$ As a consequence of the increased awareness by competent authorities, animal botulism has been included in the differential diagnosis in cases of recovery of sick or dead birds. Further efforts are needed to reduce the underreporting of outbreaks and improve awareness among veterinarians and other competent authorities. Finally, the availability of antidotes and vaccines to treat sick animals is essential to prevent additional cases.

\section{Acknowledgments}

This research was supported by the framework of the EU project AniBioThreat (Grant Agreement: Home/2009/ ISEC/AG/191) with financial support from the Prevention of and Fight against Crime Programme of the European Union, European Commission-Directorate General Home Affairs. This publication reflects the views only of the authors, and the European Commission cannot be held responsible for any use that may be made of the information contained therein.

\section{REFERENCES}

1. Hatheway CL. Clostridium botulinum and other clostridia that produce botulinum neurotoxins. In: Hauschild AHW, Dodds KL, eds. Clostridium botulinum: Ecology and Control in Food. New York: Marcel Dekker Inc.; 1992:3-20.

2. Peck MW. Biology and genetic analysis of Clostridium botulinum. Adv Microb Physiol 2009;75:183-265,320.

3. Critchley EM. A comparison of human and animal botulism: a review. J R Soc Med 1991;84:295-298.

4. Lindström M, Myllykoski J, Sivelä S, Korkeala H. Clostridium botulinum in cattle and dairy products. Crit Rev Food Sci Nutr 2010;50:281-304.

5. Rocke TE, Friend M. Avian botulism. In: Ciganovich EA, ed. Field Manual of Wildlife Diseases: General Field Procedures and Diseases of Birds. Washington, DC: US Geological Survey; 1999:271-281.

6. Arnon SS, Schechter R, Inglesby TV, et al. Botulinum toxin as a biological weapon. JAMA 2001;285:1059-1070.

7. Dembek ZF, Smith LA, Rusnak JM. Botulism: cause, effects, diagnosis, clinical and laboratory identification, and treatment modalities. Disaster Med Public Health Prep 2007;1:122-134.

8. Yeh JY, Seo HJ, Cho YS et al. Livestock agroterrorism: the deliberate introduction of a highly infectious animal pathogen. Foodborne Pathog Dis 2012;9:869-877.

9. Taylor SM, Wolfe CR, Dixon TC, Ruch DS, Cox GM. Wound botulism complicating internal fixation of a complex radial fracture. J Clin Microbiol 2010;48:650-653.

10. Takeda M, Tsukamoto K, Kohda T, Matsui M, Mukamoto M, Kozaki S. Characterization of the neurotoxin produced by isolates associated with avian botulism. Avian Dis 2005;49:376-381.

11. Takeda M, Kasai H, Torii Y, et al. Protective effect of botulinum $\mathrm{C} / \mathrm{D}$ mosaic toxoid against avian botulism. J Vet Med Sci 2006;68:325-330.

12. Nakamura K, Kohda T, Umeda K, Yamamoto H, Mukamoto M, Kozaki S. Characterization of the D/C mosaic neurotoxin produced by Clostridium botulinum associated with bovine botulism in Japan. Vet Microbiol 2010;140:147154.

13. Santos-Buelga JA, Collins MD, East AK. Characterization of the gene encoding the botulinum neurotoxin complex in a strain of Clostridium botulinum producing type B and F neurotoxins. Curr Microbiol 1998;37:312-318.

14. De Medici D, Anniballi F, Wyatt GM, et al. Multiplex PCR for detection of botulinum neurotoxin-producing clostridia in clinical, food, and environmental samples. Appl Environ Microbiol 2009;75:6457-6461.

15. Rocke TE, Samuel MD. Water and sediment characteristics associated with avian botulism outbreaks in wetlands. J Wildl Manage 1999;63:1249-1260.

16. Ortiz NE, Smith GR. The production of Clostridium botulinum type A, B and D toxin in rotting carcasses. Epidemiol Infect 1994;113:335-343.

17. Fujinaga $Y$, Inoue $K$, Watanabe $S$, et al. The haemagglutinin of Clostridium botulinum type $\mathrm{C}$ progenitor toxin plays an essential role in binding of toxin to the epithelial cells of guinea pig small intestine, leading to the efficient absorption of the toxin. Microbiology 1997;143:3841-3847. 
18. Hill KK, Xie G, Foley BT, et al. Recombination and insertion events involving the botulinum neurotoxin complex genes in Clostridium botulinum type A, B, E and $\mathrm{F}$ and Clostridium butyricum type E strains. BMC Biol 2009;7:66.

19. Marshall KM, Bradshaw M, Johnson EA. Conjugative botulinum neurotoxin-encoding plasmids in Clostridium botulinum. PLoS One 2010;5:e11087.

20. Skarin H, Håfström T, Westerberg J, Segerman B. Clostridium botulinum group III: a group with dual identity shaped by plasmids, phages, and mobile elements. BMC Genomics 2011;12:185.

21. Sakaguchi Y, Hayashi T, Kurokawa K, et al. The genome sequence of Clostridium botulinum type C neurotoxinconverting phage and the molecular mechanisms of unstable lysogeny. Proc Natl Acad Sci U S A 2005;29: 17472-17477.

22. Deprez PR. Tetanus and botulism in animals. In: Mainil J, ed. Clostridia in Medical, Veterinary and Food MicrobiologyDiagnosis and Typing. Luxembourg: European Commission; 2006;27-36.

23. Johnson AL, McAdams SC, Whitlock RH. Type A botulism in horses in the United States: a review of the past ten years (1998-2008). J Vet Diagn Invest 2010;22:165-173.

24. Johnson AL, Sweeney RW, McAdams SC, Whitlock RH. Quantitative real-time PCR for detection of neurotoxin gene of Clostridium botulinum type B in equine and bovine samples. Vet J 2012;194:118-120.

25. Wylie CE, Proudman CJ. Equine grass sickness: epidemiology, diagnosis, and global distribution. Vet Clin Equine 2009;25:381-399.

26. Lindström M, Nevas M, Kurki J, et al. Type C botulism due to toxic feed affecting 52,000 farmed foxes and minks in Finland. J Clin Microbiol 2004;42:4718-4725.

27. Myllykoski J, Lindström M, Bekema E, Pölöne I, Korkeala H. Fur animal botulism hazard due to feed. Res Vet $S_{c i}$ 2011;90:412-418.

28. Montecucco C, Schiavo G. Mechanism of action of tetanus and botulinum neurotoxins. Mol Microbiol 1994;13:1-8.

29. Simpson LL. Identification of the major steps in botulinum toxin action. Ann Rev Pharmacol Toxicol 2004;44:167-193.

30. Rocke TE. The global importance of avian botulism. In: Boere GC, Galbraith CA, Stroud DA, eds. Waterbirds Around the World. Edinburgh: Stationery Office; 2006;422426.

31. Smart JL, Jones TO, Clegg FG, McMurtry MJ. Poultry waste associated type $\mathrm{C}$ botulism in cattle. Epidemiol Infect 1987;98:73-79.

32. Jean D, Fecteau G, Scott D, Higgins R, Quessy S. Clostridium botulinum type $\mathrm{C}$ intoxication in feedlot steers being fed ensiled poultry litter. Can Vet J 1995;36:626-628.

33. Payne JH, Hogg RA, Otter HIJ, Livesey CT. Emergence of suspected type D botulism in ruminants in England and Wales (2001-2009), associated with exposure to broiler litter. Vet Rec 2011;168:640.

34. Sharpe AE, Brady CP, Moriarty J, O’Neill P, McLaughlin JG. Major outbreak of suspected botulism in a dairy herd in the Republic of Ireland. Vet Rec 2008;162:409-412.

35. Ostrowski SR, Kubiski SV, Palmero J, et al. An outbreak of equine botulism type A associated with feeding grass clippings. J Vet Diagn Invest 2012;24:601-603.
36. Roberts TA, Collings DF. An outbreak of type C botulism in broiler chickens. Avian Dis 1973;17:650-658.

37. Swerczek TW. Toxicoinfectious botulism in foals and adult horses. J Am Vet Assoc 1980;176:217-220.

38. Böhnel H, Schwagerick B, Gessler F. Visceral botulism-a new form of bovine Clostridium botulinum toxication. $J$ Vet Med A Physiol Pathol Clin Med 2001;48:373-383.

39. Liguori V, De Luliis P, Fenicia F, Anniballi F, Aureli P. A case of wound botulism in a foal affected by gastric ulcers in Italy. J Equine Vet Sci 2008;28:476-478.

40. Hogg R, Livesey C, Payne J. Diagnosis and implications of botulism. In Practice 2008;30:392-397.

41. Neimanis A, Gavier-Widén D, Leighton F, Bollinger T, Rocke T, Mörner T. An outbreak of type $\mathrm{C}$ botulism in herring gulls (Larus argentatus) in southern Sweden. J Wildl Dis 2007;43:327-336.

42. Dohms JE, Allen PH, Rosenberger JK. Case of type C botulism in broiler chickens. Avian Dis 1981;26:204-210.

43. Sharpe AE, Sharpe EJ, Ryan ED, Clarke HJ, McGettrick SA. Outbreak of type $\mathrm{C}$ botulism in laying hens. Vet Rec 2011:168;669a.

44. Quortrup ER, Gorham JR. Susceptibility of furbearing animals to the toxins Clostridium botulinum types A, B, C, and E. Am J Vet Res 1949;10:268-271.

45. Kelch WJ, Kerr LA, Pringle JK, Rohrbach BW, Whitlock RH. Fatal Clostridium botulinum toxicosis in eleven Holstein cattle fed round bale barley haylage. J Vet Diagn Invest 2000;12:453-455.

46. Aleman M, Williams DC, Jorge NE, et al. Repetitive stimulation of the common peroneal nerve as a diagnostic aid for botulism in Foals. J Vet Intern Med 2011;25:356-372.

47. Anniballi F, Auricchio B, Delibato E, Antonacci M, De Medici D, Fenicia L. Multiplex real-time PCR SYBR Green for detection and typing of group III Clostridium botulinum. Vet Microbiol 2012;154:332-338.

48. Allison MJ, Maloy SE, Matson RR. Inactivation of Clostridium botulinum toxin by ruminal microbes from cattle and sheep. Appl Environ Microbiol 1976;32:685-688.

49. Hedeland M, Moura H, Båverud V, Woolfitt AR, Bondesson U, Barr JR. Confirmation of botulism in birds and cattle by the mouse bioassay and Endopep-MS. J Med Microbiol 2011;60:1299-1305.

50. Woudstra C, Skarin H, Anniballi F, et al. Neurotoxin gene profiling of Clostridium botulinum types $\mathrm{C}$ and D native to different countries within Europe. Appl Environ Microbiol 2012;78:3120-3127.

51. Martin S. Clostridium botulinum type D intoxication in a dairy herd in Ontario. Can Vet J 2003;44:493-495.

52. Braun U, Feige K, Schweizer G, Pospischil A. Clinical findings and treatment of 30 cattle with botulism. Vet Rec 2005;156:438-441.

53. Regulation (EC) No 1774/2002 of the European Parliament and of the Council of the October 2002, laying down health rules concerning animal by-products not intended for human consumption. http://eur-lex.europa.eu/LexUriserv/site/en/ consleg/2002/R/02002R1774-20060401-en.pdf. Accessed August 13, 2013.

54. Council Directive 2007/43/EC of 28 June 2007, laying down minimum rules for the protection of chickens kept for meat production. http://ec.europa.eu/health/medical-devices/ files/revision_docs/2007-47-en_en.pdf. Accessed August 13, 2013.

Biosecurity and Bioterrorism: Biodefense Strategy, Practice, and Science 
55. Cobb SP, Hogg RA, Challoner DJ, et al. Suspected botulism in dairy cows and its implication for the safety of human food. Vet Rec 2002;150:5-8.

56. Myllykoski J, Linström M, Keto-Timonen R, et al. Type C bovine botulism outbreak due to carcass contaminated nonacid silage. Epidemiol Infect 2009;137:284-93.

57. Duncan RM, Jensen WI. A relationship between avian carcasses and living invertebrates in the epizootiology of avian botulism. J Wildl Dis 1976;12:116-126.

58. Evelsizer DD, Clark RG, Bollinger TK. Relationship between local carcass density and risk of mortality in molting mallards during avian botulism outbreaks. J Wildl Dis 2010;46:507-513.

59. Directive 2001/82/EC of the European Parliament and of the Council of 6 November 2001 on the community code relating to veterinary medical products. http://ec.europa.eu/ health/files/eudralex/vol-5/dir_2001_82/dir_2001_82_en.pdf. Accessed August 13, 2013.

60. Steinman A, Chaffer M, Elad D, Shpigel NY. Quantitative analysis of level of serum immunoglobulin G against botulinum neurotoxin type $\mathrm{D}$ and association with protection in natural outbreaks of cattle botulism. Clin Vaccine Immunol 2006;13:862-868.

61. Martinez R, Wobeser G. Immunization of ducks for type C botulism. J Wildl Dis 1999;35:710-715.

62. Dohms JE, Allen PH, Cloud SS. The immunization of broiler chickens against type C botulism. Avian Dis 1982;26: 340-345.
63. Sprayberry KA. Botulism: a perfect killer. Horse 2007; article 20150.

64. Bell FJ, Farrel KR, Gorham JR. A polyvalent toxoid for botulism in mink. Am J Vet Res 1957;18:167-170.

65. AniBioThreat. Animal Botulism in Europe: Current Status of an Emerging Disease. Abstracts of reports of botulism in animals over the last decade written by participants of the Animal Botulism Workshop. Report No. 17. Uppsala; 2012.

66. Directive 2003/99/EC of the European parliament and of the Council of 17 November 2003 on the monitoring of zoonoses and zoonotic agents, amending Council Decision 90/424/EEC and repealing Council Directive 92/117/EEC. http://eur-lex.europa.eu/LexUriServ/LexUriServ.do?uri=OJ:L: 2003:325:0031:0040:EN:PDF. Accessed August 13, 2013.

Manuscript received December 27, 2012; accepted for publication April 23, 2013.

Address correspondence to:

Dario De Medici, PhD Senior Researcher Istituto Superiore di Sanità (ISS)

Department of Veterinary Public Health and Food Safety

Viale Regina Elena 299

Rome 00161 Italy

E-mail: dario.demedici@iss.it 